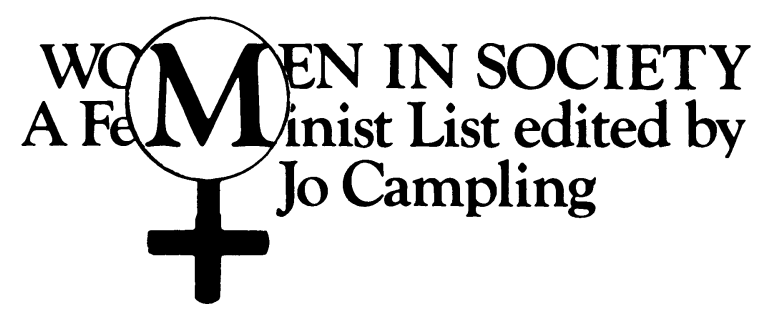

editorial advisory group

Maria Brenton, University College, Cardiff; Phillida Bunckle, Victoria University, Wellington, New Zealand; Miriam David, Polytechnic of the South Bank; Leonore Davidoff, University of Essex; Janet Finch, University of Lancaster; Jalna Hanmer, University of Bradford; Beverley Kingston, University of New South Wales, Australia; Hilary Land, Royal Holloway and Bedford New College, University of London; Diana Leonard, University of London Institute of Education; Susan Lonsdale, Polytechnic of the South Bank; Jean O'Barr, Duke University, North Carolina, USA; Arlene Tigar McLaren, Simon Fraser University, British Columbia, Canada; Jill Roe, Macquarie University, Australia; Hilary Rose, University of Bradford; Susan Sellers, Centre D'Etudes Féminines, Université de Paris, France; Pat Thane, Goldsmiths' College, University of London; Clare Ungerson, University of Kent at Canterbury; Judy Walkowitz, Rutgers University, New Jersey, USA.

The 1970s and 1980s have seen an explosion of publishing by, about and for women. This new list is designed to make a particular contribution to this process by commissioning and publishing books which consolidate and advance feminist research and debate in key areas in a form suitable for students, academics and researchers but also accessible to a broader general readership.

As far as possible books will adopt an international perspective incorporating comparative material from a range of countries where this is illuminating. Above all they will be interdisciplinary, aiming to put women's studies and feminist discussion firmly on the agenda in subject-areas as disparate as law, physical education, art and social policy. 


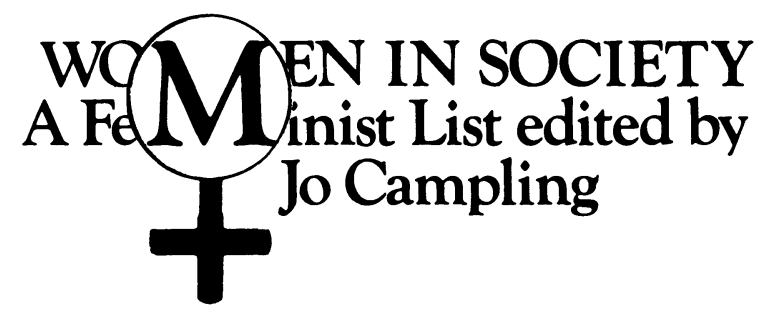

\section{Published}

Sheila Allen and Carol Wolkowitz Homeworking: myths and realities

Niamh Baker Happily Ever After? Women's fiction in postwar Britain, 1945-60

Jenny Beale Women in Ireland: voices of change

Ruth Carter and Gill Kirkup Women in Engineering

Angela Coyle and Jane Skinner (editors) Women and Work: positive action for change

Gillian Dalley Ideologies of Caring: rethinking community and collectivism

Leonore Davidoff and Belinda Westover (editors) Our Work, Our Lives, Our Words: women's history and women's work

Emily Driver and Audrey Droisen (editors) Child Sexual Abuse: feminist perspectives

Diana Gittins The Family in Question: changing households and familiar ideologies

Tuula Gordon Feminist Mothers

Frances Heidensohn Women and Crime

Ursula King Women and Spirituality: voices of protest and promise

Muthoni Likimani (Introductory Essay by Jean O'Barr) Passbook Number F.47927: women and Mau Mau in Kenya

Jo Little, Linda Peake and Pat Richardson (editors) Women in Cities: gender and the urban environment

Sharon Macdonald, Pat Holden and Shirley Ardener (editors) Images of Women in Peace and War: cross-cultural and historical perspectives

Shelley Pennington and Belinda Westover A Hidden Workforce: homeworkers in England, 1850-1985

Vicky Randall Women and Politics: an international perspective (2nd edn)

Rosemary Ridd and Helen Callaway (editors) Caught Up in Conflict: women's responses to political strife

Patricia Spallone Beyond Conception: the new politics of reproduction

Taking Liberties Collective Learning the Hard Way: women's oppression in men's education

Clare Ungerson (editor) Women and Social Policy: a reader

Annie Woodhouse Fantastic Women: sex, gender and transvestism

\section{Forthcoming}

Eileen Aird and Judy Lown Education for Autonomy: processes of change in women's education Jennifer Breen Women and Fiction

Maria Brenton Women and Old Age

Joan Busfield Women and Mental Health

Lesley Ferris Acting Women: images of women in theatre

Frances Gray Women and Laughter

Eileen Green, Diana Woodward and Sandra Hebron Women's Leisure, What Leisure?

Jennifer Hargreaves Women and Sport

Annie Hudson Troublesome Girls: adolescence, femininity and the state

Susan Lonsdale Women and Disability

Mavis Maclean Surviving Divorce: women's resources after separation

Lesley Rimmer Women's Family Lives: changes and choices

Susan Sellers Language and Sexual Difference: feminist writing in France

Deborah Valenze The Other Victorian Women

Janet Wolff The Art of Women 


\title{
Feminist Mothers
}

\author{
Tuula Gordon
}

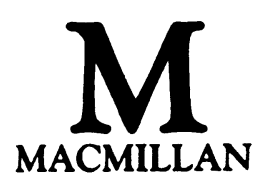




\section{(C) Tuula Gordon 1990}

Reprint of the original edition 1990

All rights reserved. No reproduction, copy or transmission of this publication may be made without written permission.

No paragraph of this publication may be reproduced, copied or transmitted save with written permission or in accordance with the provisions of the Copyright Act 1956 (as amended), or under the terms of any licence permitting limited copying issued by the Copyright Licensing Agency, 33-4 Alfred Place, London WC1E 7DP.

Any person who does any unauthorised act in relation to this publication may be liable to criminal prosecution and civil claims for damages.

First published 1990

Published by

MACMILLAN EDUCATION LTD

Houndmills, Basingstoke, Hampshire RG21 2XS

and London

Companies and representatives

throughout the world

Typeset by Vine \& Gorfin Ltd

Exmouth, Devon

British Library Cataloguing in Publication Data

Gordon, Tuula

Feminist mothers. - (Women in society)

1. Motherhood. Attitudes to mothers

I. Title II. Series

306. $8^{\prime} 743$

ISBN 978-0-333-44658-4 ISBN 978-1-349-20292-8 (eBook)

DOI 10.1007/978-1-349-20292-8

\section{Series Standing Order}

If you would like to receive future titles in this series as they are published, you can make use of our standing order facility. To place a standing order please contact your bookseller or, in case of difficulty, write to us at the address below with your name and address and the name of the series. Please state with which title you wish to begin your standing order. (If you live outside the United Kingdom we may not have the rights for your area, in which case we will forward your order to the publisher concerned.)

Customer Services Department, Macmillan Distribution Ltd, Houndmills, Basingstoke, Hampshire, RG21 2XS, England. 


\section{Contents}

Acknowledgements vi

Introduction 1

1. Structures, cultures and personal lives 7

2. Processes and outcomes: socialisation into femininity 21

3. Feminism: differences and alternatives 36

4. Motherhood and subjective experience 49

5. Work-yes, careers-no 65

6. Children and partners 79

7. Pleasures and gains: contradictions and difficulties 105

8. What is a feminist mother? 125

Appendix: the interviewees 151

Notes 153

References 156

Index 163 


\section{Acknowledgements}

This book began while I was working with the Girls and Occupational Choice project at the University of London Institute of Education in a fruitful and productive environment. I have carried the book with me through Helsinki University Sociology Department to the Department of Sociology of Education at the University of Joensuu. I would like to thank the Finnish Academy, who partly funded the work. Various people have been influential in the shaping of this book, and numerous discussions have been interesting and stimulating. I would like to name some of those who have given me food for thought and read sections of the manuscript: Lynne Chisholm, Dougie Gordon, Janet Holland, Marja Holmila, Pertti Koistinen, Leena Koski, Eeva Peltonen, Vesa Puuronen and Liisa Rantalaiho. The following organisations were helpful: Maternity Alliance, Hackney African Organisation, and in Finland Yksinhuoltajien liitto, Social Democratic Women, Folk Democratic Women, SETA and Unioni Naisasialiitto. The editor of the series, Jo Campling, deserves to be thanked; she has always been very encouraging at appropriate points. I would like to thank all the women who agreed to be interviewed; though the writing of this book has, on the whole, been interesting, no doubt the most memorable and interesting part for me was meeting all of them. I am grateful to them for sharing their thoughts with me; if this book is a product of those meetings, they meant a great deal to me personally as well. Last but not least, I am indebted to the members of my family, Dougie, Mikko and Janne; I thank them for their support during what has in many ways been a period of change in our lives. I am additionally grateful to Dougie for proof-reading the whole manuscript. 